\title{
New species of Oculatella (Synechococcales, Cyanobacteria) from terrestrial habitats of Ukraine
}

\author{
Oxana VINOGRADOVA ${ }^{1}$, Tatiana MIKHAILYUK ${ }^{1}$, Karin GLASER ${ }^{2}$, \\ Andreas HOLZINGER ${ }^{3}$, Ulf KARSTEN² \\ ${ }^{1}$ M.G. Kholodny Institute of Botany, NAS of Ukraine \\ 2, Tereshchenkivska St., Kyiv 01004, Ukraine \\ ${ }^{2}$ University of Rostock, Institute of Biol. Sci., Department of Appl. Ecology and Phycology \\ 3, Albert-Einstein-Strasse, Rostock D-18057, Germany \\ ${ }^{3}$ University of Innsbruck, Department of Botany, Functional Plant Biology \\ Sternwartestrasse 15, Innsbruck A-6020, Austria
}

Vinogradova O., Mikhailyuk T., Glaser K., Holzinger A., Karsten U. New species of Oculatella (Synechococcales, Cyanobacteria) from terrestrial habitats of Ukraine. Ukr. Bot. J., 2017, 74(6): 509-520.

Abstract. Here we describe two new species of Oculatella Zammit, Billi \& Albertano from terrestrial habitats of Ukraine: $O$. ucrainica sp. nov. and O. kazantipica sp. nov. The strains were isolated from biological crusts collected at the Sea of Azov conqina beach, and both clay slopes and chalk outcrops in the Kharkiv Region. Five strains evaluated in this study phenotypically and phylogenetically differed both among each other and from other species of this genus. On the phylogenetic tree based on 16S $r$ RNA gene sequence comparison, original strains joined already known species of Oculatella forming isolated lineages, one of which joined the group of drought-resistant terrestrial species $(O$. ucrainica $)$, while another $(O$. kazantipica) grouped together with terrestrial $O$. neakameniensis Kováčik et Johansen and aquatic $O$. hafneriensis Kováčik et Johansen. The phylogeny based on the 16S $r$ RNA gene concatenated with the 16S-23S ITS region, as well as secondary structures of the most informative helices of the 16S-23S ITS confirmed new species designation. Filaments of $O$. ucrainica are narrower $(1.5-3.0 \mu \mathrm{m})$, and trichomes are wider $(1.3-2.7 \mu \mathrm{m})$ comparing to $O$. kazantipica (its filaments are $1.3-7.5 \mu \mathrm{m}$ wide, trichomes $1.1-1.7 \mu \mathrm{m}$ wide). The new species also differ from one another in sheath morphogenesis, appearence of trichomes, and cell length. Oculatella ucrainica morphologically and phylogenetically is close to desert species $O$. coburnii Pietrasiak et Johansen, differing in the higher degree of sheath formation, wider trichomes, apical cells without irregular outgrowth, and by composition and secondary structure of $16 \mathrm{~S}-23 \mathrm{~S}$ ITS region. $O$. kazantipica is similar to $O$. hafneriensis and $O$. neakameniensis, from which it differs in more abundant sheath, false branching, granulations at cross walls, longer intercalary cells, and by composition and secondary structure of its 16S-23S ITS region.

Keywords: Synechococcales, Oculatella ucrainica, Oculatella kazantipica, new species, biological crusts, Ukraine, molecular sequencing, 16S $r$ RNA, 16S-23S ITS, secondary structure

Supplementary Material. Electronic Supplement (Table E1, p. e1) is available in the online version of this article at: https://ukrbotj.co.ua/archive/74/6/509

\section{Introduction}

The genus Oculatella Zammit, Billi \& Albertano, which is morphologically similar to the genus Leptolyngbya Anagnostidis \& Komárek, was separated from the latter on the basis of differences in sequence of the 16S $r$ RNA gene and the secondary structure of the 16S-23S ITS region (Zammit et al., 2012; Osorio-Santos et al., 2014). The name of the genus is due to the photosensitive reddish eyespot (oculus) at the tip of mature apical cells, clearly visible in a light microscope. Recently, we reported the discovery on the Sea of Azov coast morphotypes of thin filamentous cyanobacteria possessing mentioned

(C) O. VINOGRADOVA, T. MIKHAILYUK, K. GLASER, A. HOLZINGER, U. KARSTEN, 2017 autapomorph and with nucleotide sequence of the $16 \mathrm{~S}$ $r$ RNA gene completely corresponding to Oculatella (Mikhailyuk et al., 2016). A new detailed analysis of these strains, based on the phylogeny of the $16 \mathrm{~S} r \mathrm{RNA}$ gene concatenated with the 16S-23S ITS region, as well as secondary structures of the most informative helices of the 16S-23S ITS, showed that our strains differ from all known Oculatella species. Further morphological observations and molecular study of the isolated strains revealed that in the crusts of seaside habitats, in fact, there are two species, each having a number of differences from known representatives of this genus. In parallel, studying samples of cyanobacterial crusts from several areas of the cretaceous outcrops in Kharkiv Region, we also found morphotypes of Oculatella, 
which we managed to isolate into culture. It turned out that one of these strains morphologically, as well as by a number of molecular markers, completely coincides with the three strains from the seacoast.

The paper reports on two new species of Oculatella from the terrestrial environments of Ukraine described using combined molecular and morphological data.

\section{Materials and methods}

Isolation of the strains, culture conditions, light and transmission electron microscopy

The strains in this study were isolated from the samples of biological soil crusts collected on the coast of the Sea of Azov in Kazantip Nature Reserve (Leninsky District, the Crimea) and at the chalk outcrops in Dvorichansky District of Kharkiv Region (Table 1). Sampling and processing of collected material were described in details in our previous paper (Mikhailyuk et al., 2016).

All strains were maintained on 1N BBM (Bischoff and Bold, 1963) and BG-11 (Stanier et al., 1971) agarized media at $12: 12$ light : dark photoperiod at $+20 \pm 5^{\circ} \mathrm{C}$. Morphological examinations of cultures of cyanobacteria starting from 2 weeks and up to 6 months of cultivation were performed using Olympus BX51 light microscope with Nomarski DIC optics. Photomicrographs were taken from live material with digital camera Olympus UC30 attached to the microscope and processed by software cellSens Entry.

Reference cultures of newly described species (KZ5-4-1 and KZ-19-s-2) were deposited in the culture collection of University of Göttingen, Germany ( $S A G$ 2563, 2567). All other Oculatella strains are maintained in the algal culture collection at University of Rostock, Germany. For each newly described Oculatella species, a herbarium accession was prepared. Young (3-4 weeks) cultures of reference strains were preserved in $4 \%$ formaldehyde in a $15 \mathrm{~mL}$ glass bottle. The preserved material was then deposited in the Herbarium of the M.G. Kholodny Institute of Botany, NAS of Ukraine ( $K W-A$ 32375-32376).

Samples were fixed for transmission electron microscopy (TEM) using a standard chemical fixation protocol $\left(2.5 \%\right.$ glutaraldehyde, $1 \% \mathrm{OsO}_{4}$ in $10 \mathrm{mM}$ caccodylate buffer, $\mathrm{pH}$ 6.8) according to Holzinger et al. (2009). Samples were dehydrated in increasing ethanol concentrations, transferred to modified Spurr's resin and heat polymerized. For TEM, ultrathin sections were prepared, counterstained with uranyl acetate and Reynold's lead citrate, and investigated by a Zeiss
LIBRA 120 transmission electron microscopes at $80 \mathrm{kV}$. Images were captured with a TRS 2k SSCCD camera and further processed using Adobe Photoshop software (Adobe Systems Inc., San José, California, USA).

DNA isolation, PCR, sequencing and phylogenetic analysis

DNA of the cyanobacterial strains was extracted using the DNeasy Plant Mini Kit (Qiagen GmbH, Hilden, Germany) according to the manufacturer's instructions. Nucleotide sequences of the 16S $r$ RNA gene together with 16S-23S ITS region were amplified using Taq PCR Mastermix Kit (Qiagen $\mathrm{GmbH}$ ) and primers SSU-4-forw and ptLSU C-D-rev (Marin et al., 2005) in a thermocycler Tgradient Thermoblock (Biometra, Germany) under the conditions described in our previous paper (Mikhailyuk et al., 2016). PCR products were cleaned using a Qiagen PCR purification kit (Qiagen $\mathrm{GmbH}$ ) according to the manufacturer's instructions. Cleaned PCR products were sequenced commercially by Qiagen Company using primers SSU-4-forw, Wil 6, Wil 12, Wil 14, Wil 5, Wil 9, Wil 16 and ptLSU C-D-rev (Wilmotte et al., 1993; Marin et al., 2005). The resulting sequences were assembled and edited using Geneious software (version 8.1.8; Biomatters). They were deposited in GenBank under the accession numbers MG652616-MG652620.

For comparison with five original strains, we used 63 nucleotide sequences of representatives of the order Synechococcales available in GenBank (NCBI*). Sequence of Oculatella hafneriensis Kováčik et Johansen used in the study was provided by Jeffrey R. Johansen (John Carroll University, University Heights, USA) during personal communication and deposited by us in GenBank under the accession number and authorship of mentioned person. Sequence of $O$. hafneriensis previously deposited in GenBank (DQ085093) has some doubtful parts and lacking the 16S-23S ITS region.

Multiple alignment of the nucleotide sequences for phylogeny based on the 16S $r$ RNA gene was made using Mafft web server (version 7, Katoh and Standley, 2013) followed by manual editing in the program BioEdit (version 7.2). Alignment for the phylogeny of the 16S-23S ITS region was performed manually in BioEdit, taking into account the secondary structure of the RNA in the region. The evolutionary model that is best suited to the used database was selected on the basis of the lowest AIC value (Akaike, 1974) calculated in MEGA (version 6, Tamura et al., 2013). Phylogenetic

* See the Electronic Supplement in the online version of the article: https://ukrbotj.co.ua/archive/74/6/509 
Table 1. Sampling sites for the Oculatella strains reported in this study

\begin{tabular}{|c|c|c|c|c|}
\hline Strain ID & Location & GPS-coordinates & $\begin{array}{l}\text { Sampling } \\
\text { date }\end{array}$ & Site description \\
\hline KZ-5-4-1 & $\begin{array}{c}\text { The coast of the Sea of Azov, vicinities of } \\
\text { Kazantip Nature Reserve, spit of } \\
\text { Aqtash Lake }\end{array}$ & $45^{\circ} 43^{\prime} 85^{\prime \prime} \mathrm{N} 35^{\circ} 85^{\prime} 25^{\prime \prime} \mathrm{E}$ & 08.08 .2012 & $\begin{array}{c}\text { Coquina beach, } 10 \mathrm{~m} \text { from the water's edge, } \\
\text { cyanobacterial-algal crusts with dominance } \\
\text { of Nostoc edaphicum Kondrat. }\end{array}$ \\
\hline KZ-7-1-4 & $\begin{array}{c}\text { The coast of the Sea of Azov, vicinities of } \\
\text { Kazantip Nature Reserve, spit of } \\
\text { Aqtash Lake }\end{array}$ & $45^{\circ} 43^{\prime} 85^{\prime \prime} \mathrm{N} 35^{\circ} 85^{\prime} 25^{\prime \prime} \mathrm{E}$ & 08.08 .2012 & $\begin{array}{l}\text { Coquina beach, } 10 \mathrm{~m} \text { from the water's edge, } \\
\text { cyanobacterial-algal crusts with dominance } \\
\text { of Nostoc edaphicum and Hassalia sp. }\end{array}$ \\
\hline KZ-12-1 & $\begin{array}{c}\text { The coast of the Sea of Azov, Kazantip } \\
\text { Nature Reserve, Sharabay Bay }\end{array}$ & $45^{\circ} 46^{\prime} 76^{\prime \prime} \mathrm{N} 35^{\circ} 84^{\prime} 04^{\prime \prime} \mathrm{E}$ & 10.08 .2012 & $\begin{array}{c}\text { Clay slope with sparse steppe vegetation, } \\
\text { hypolithic under quartz fragments together } \\
\text { with other cyanobacteria and algae }\end{array}$ \\
\hline KZ-19-s-2 & $\begin{array}{c}\text { The coast of the Sea of Azov, Kazantip } \\
\text { Nature Reserve, Shyrokaya Bay }\end{array}$ & $45^{\circ} 47^{\prime} 04^{\prime \prime} \mathrm{N} 35^{\circ} 85^{\prime} 47^{\prime \prime} \mathrm{E}$ & 07.08 .2012 & $\begin{array}{c}\text { Coquina beach, cyanobacterial-algal crusts } \\
\text { with dominance of Microcoleus vaginatus } \\
\text { Gomont ex Gomont }\end{array}$ \\
\hline
\end{tabular}

trees were constructed in the program MrBayes 3.2.2 (Ronquist, Huelsenbeck, 2003), using an evolutionary model GTR + G + I, with 5,000,000 generations. Two of the four runs of Markov chain Monte Carlo were made simultaneously, with the trees, taken every 500 generations. Split frequencies between runs at the end of calculations were below 0.01 . The trees selected before the likelihood rate reached saturation were subsequently rejected. The reliability of tree topology verified by the maximum likelihood analysis (ML) were made using the program GARLI 2.1. Models of the secondary structure of $16 \mathrm{~S}-23 \mathrm{~S}$ ITS region of the original strains were built according to published data (Osorio-Santos et al., 2014). Helices were folded with the online software mfold (Zuker, 2003) and visualized in the online tool Pseudoviewer (Byun, Han, 2009).

\section{Results and discussion}

The study of enrichment cultures of the samples of biological crusts from the coast of the Sea of Azov and chalk outcrops in Kharkiv Region revealed that thin filaments with reddish eyespot in mature apical cells occur quite common: we found them in $57 \%$ of the samples from the sea coast and $69 \%$ from chalks. Morphological evaluation of selected original strains (Table 2) confirmed taxonomical designation into the genus Oculatella. Phylogenetic analysis based on 16S $r$ RNA gene sequence comparison supported this matching. Our strains, morphologically attributed to genus Oculatella, on the phylogenetic tree joined already known species of this genus, forming an isolated clade (Fig. 1). More detailed phylogenetic analysis on the base of 16S $r$ RNA gene sequence concatenated with the $16 \mathrm{~S}-23 \mathrm{~S}$ ITS region reflected differences in gene identities of the original strains. One of the seaside strains (KZ-19-s-2) grouped in subclade with O. hafneriensis Kováčik et Johansen and $O$. neakameniensis Kováčik et Johansen, while the other three together with "chalky" strain joined the group of drought-resistant terrestrial species of Oculatella inhabiting arid to semi-arid desert soils: O. atacamensis Osorio-Santos et Johansen, $O$. mojaviensis Pietrasiak et Johansen and $O$. coburnii Pietrasiak et Johansen (Osorio-Santos et al., 2014). The four strains (KZ-5-4-1, KZ-7-1-4, KZ-12-1 and Vin-4-4-1) represent a new species $O$. ucrainica sp. nov. (see below); the fifth strain (KZ-19-s-2) despite closeness to $O$. neakameniensis and $O$. hafneriensis formed a highly supported separate lineage which corresponded to another new species described here as O. kazantipica sp. nov. (see below).

Comparison of the main helices of 16S-23S ITS secondary structure of our isolates and phylogenetically close species (Fig. 3) showed general similarity of all Oculatella strains especially in structure of D1-D1' and Box-B helices. Our newly described species differ from close known taxa by one unique base in D1D1' and Box-B helices (O. ucrainica) and by two unique bases in D1-D1' helix and one unique base in Box-B helix (O. kazantipica). V-3 helix is quite similar in all compared taxa, but has the most unique base composition in $O$. hafneriensis (15 unique bases). $O$. neakameniensis differs as well by unique structure 


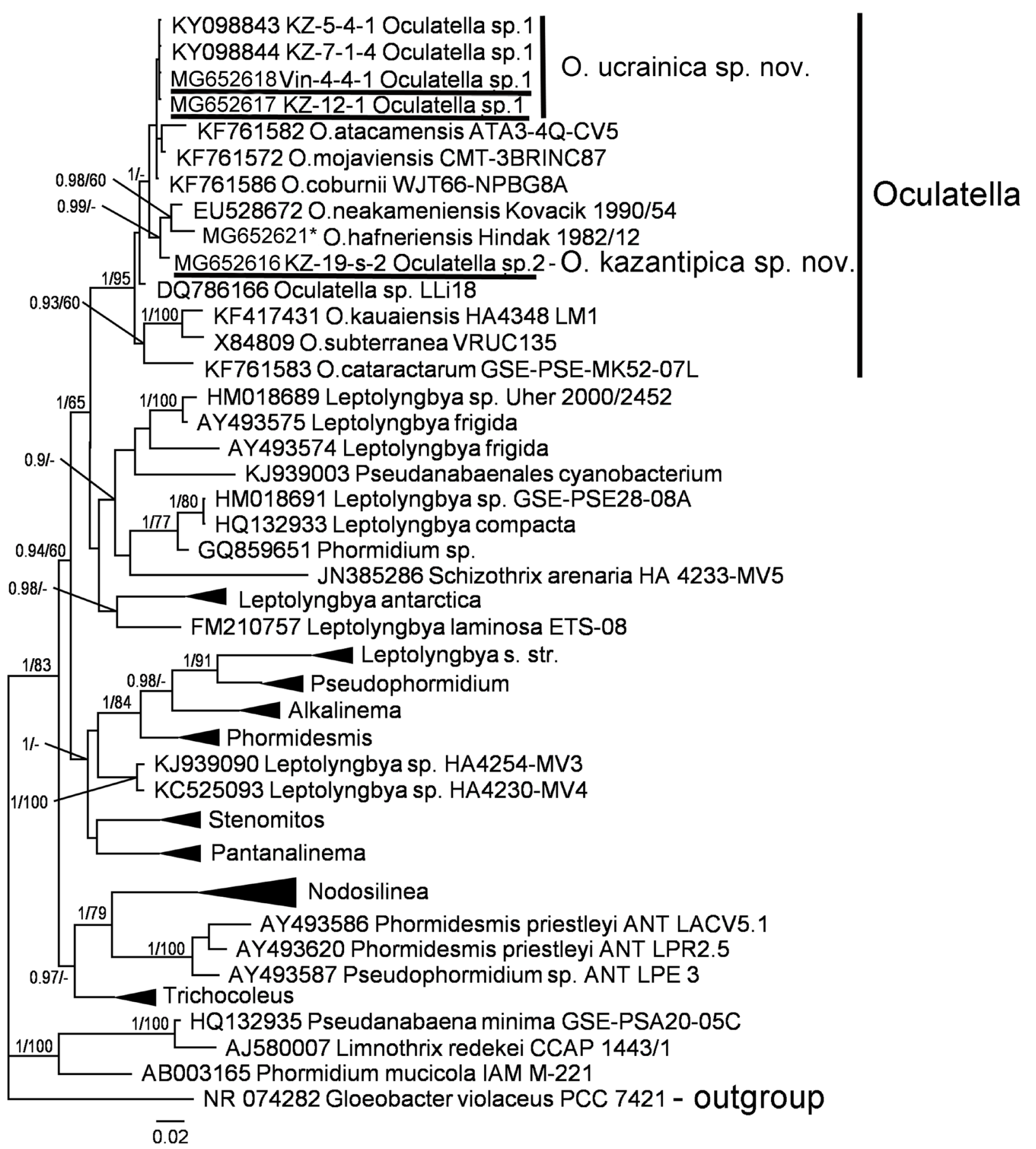

Fig. 1. Molecular phylogeny of Synechococcales based on 16S $r$ RNA sequence comparisons. A phylogenetic tree was inferred by the Bayesian method with Bayesian Posterior Probabilities (PP) and Maximum Likelihood bootstrap support (BP) indicated at nodes. From left to right, support values correspond to Bayesian PP and Maximum Likelihood BP; BP values lower than 50\% and PP lower than 0.8 not shown. Strains marked with underline are newly sequenced cyanobacteria. Clade designations follow Osorio-Santos et al., 2014 and Miscoe et al., 2016

* Sequence of Oculatella hafneriensis used in the study was provided by Jeffrey R. Johansen (John Carroll University, University Heights, USA) via personal communication. 


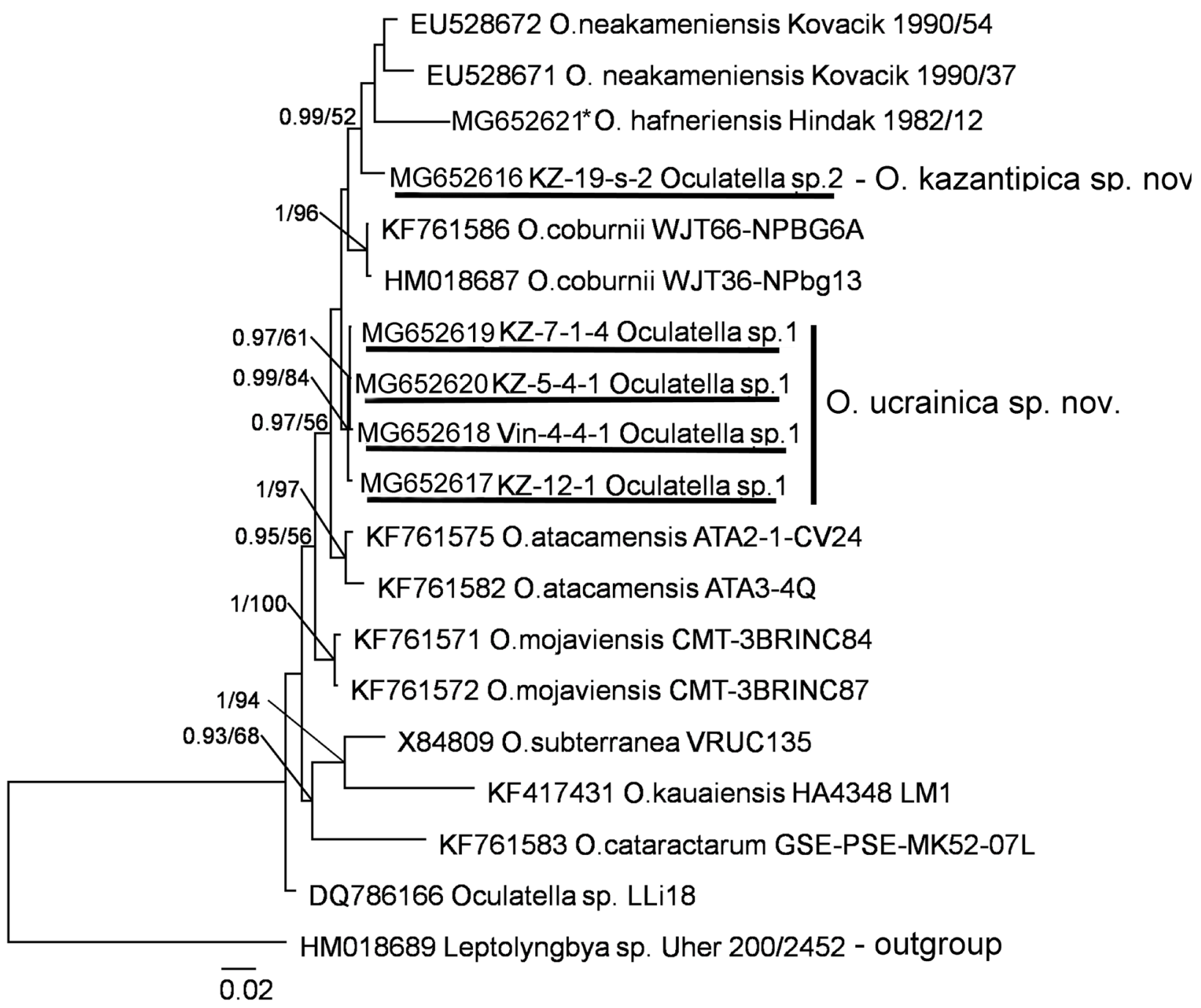

Fig. 2. Molecular phylogeny of genus Oculatella based on 16S-23S ITS sequence comparisons. A phylogenetic tree was inferred by the Bayesian method with Bayesian Posterior Probabilities (PP) and Maximum Likelihood bootstrap support (BP) indicated at nodes. From left to right, support values correspond to Bayesian PP and Maximum Likelihood BP; BP values lower than 50\% and PP lower than 0.8 not shown. Strains marked with underline are newly sequenced cyanobacteria 

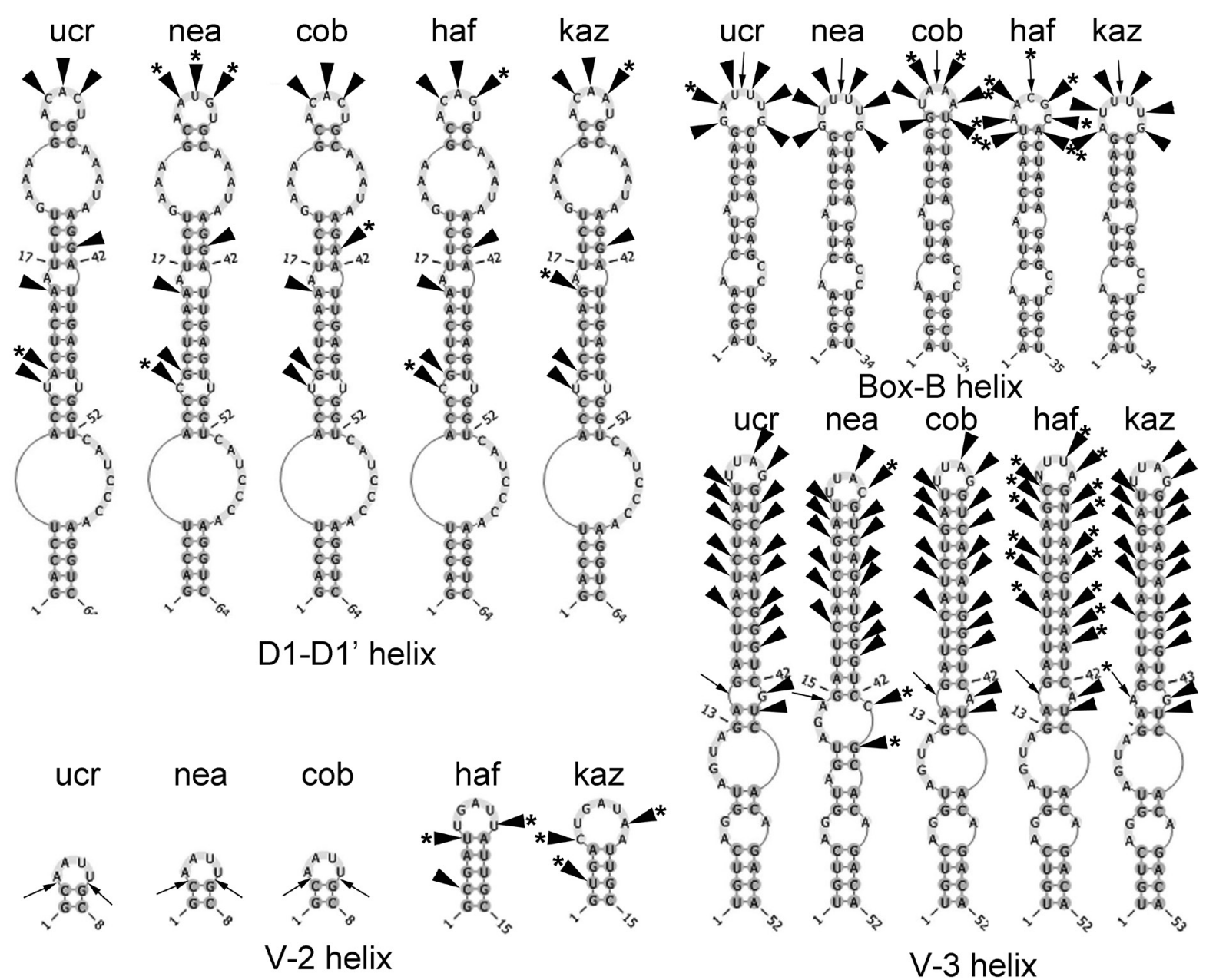

Fig. 3. Secondary structure of the main informative helices of region 16S-23S ITS of newly described species (Oculatella ucrainica (ucr) and $O$. kazantipica (kaz)) and comparison with the most close known species of Oculatella $(O$. neakameniensis (nea), O. coburnii (cob) and $O$. hafneriensis (haf)). Variable bases are shown with arrowheads, places of insertions/deletions of base pairs are marked with arrows, unique bases are indicated with asterisk

of V-3 helix in the base part due to one unique base difference. Our new species have V-3 helices similar to $O$. coburnii, but differed by one base in the basal loop (O. ucrainica and O. kazantipica) and by one unique insertion (O. kazantipica). V-2 helix of $O$. ucrainica was identical with the helices of all terrestrial species of Oculatella. O. kazantipica had V-2 helix similar to $O$. hafneriensis but differed by 3 unique bases.

Revealed morphotypes differ both among the two new species and from other species of Oculatella (Table 2, Figs 4, 5). As can be seen from the table and figures, the width range of the filaments in O. kazantipica (1.3$7.5 \mu \mathrm{m}$ ) is significantly higher than that of $O$. ucrainica $(1.5-3.0 \mu \mathrm{m})$; it relates to the different nature of the sheath formation in these species. In old cultures of both species, the sheath became broader and stronger, but in $O$. ucrainica the extension of the filament is because the sheath somewhat retreated from the trichome, whereas in $O$. kazantipica the sheath gradually expanded, sometimes becoming lamellar. The new species also differ one another in appearance and trichome width. Trichomes of $O$. ucrainica are broader $(1.3-2.7 \mu \mathrm{m})$, clearly constricted and rarely with granulations at cross walls. In contrast, $O$. kazantipica trichomes unconstricted or weakly constricted but usually with granulations at crosswalls; the width of the trichome $(1.1-1.7 \mu \mathrm{m})$ is smaller, but the length of the cells (4.7$7.5 \mu \mathrm{m}$ ) exceeds that of the first species (Table 2).

From the type species $O$. subterranea Zammit, Billi et Albertano both new species differ by the blue-green 
Table 2. Morphological comparison of Oculatella ucrainica sp. nov. and O. kazantipica sp. nov. with known* Oculatella species**

\begin{tabular}{|c|c|c|c|c|c|c|c|c|c|c|}
\hline Species & 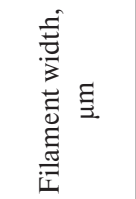 & 壱 & 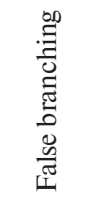 & 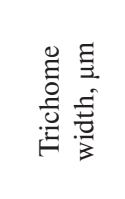 & 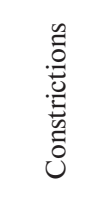 & 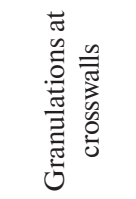 & $\begin{array}{l}\frac{\pi}{\pi} \\
\frac{\pi}{0} \\
\text { Z }\end{array}$ & 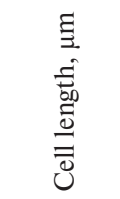 & 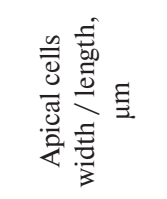 & 营 \\
\hline O. atacamensis & $1.8-4.1$ & common & rare & $1.5-2.3$ & weak & sometimes & - & $1.5-7.4$ & $\begin{array}{c}1.4-2.1 / \\
2.5-9.9\end{array}$ & $\begin{array}{c}\text { Soils and } \\
\text { under quartz } \\
\text { rocks in desert }\end{array}$ \\
\hline O. mojaviensis & $2.0-2.6$ & common & rare & $1.6-2.2$ & $\begin{array}{c}\text { absent/ } \\
\text { weak }\end{array}$ & sometimes & + & $1.5-5.0$ & $\begin{array}{c}1.4-2.0 / \\
2.4-6.8 \\
\end{array}$ & $\begin{array}{l}\text { Dolomitic soil } \\
\text { in hot desert }\end{array}$ \\
\hline O. neakameniensis & $1.2-4.1$ & common & absent & $1.2-1.7$ & $\begin{array}{c}\text { absent/ } \\
\text { weak }\end{array}$ & sometimes & - & $1.5-5.4$ & $\begin{array}{c}1.1-1.7 / \\
2.3-7.7\end{array}$ & $\begin{array}{c}\text { Semi-arid } \\
\text { volcanic soil }\end{array}$ \\
\hline O. cataractarum & $1.3-1.7$ & rare & rare & $\begin{array}{c}0.8-1.3- \\
(1.7)\end{array}$ & $\begin{array}{c}\text { absent/ } \\
\text { weak }\end{array}$ & frequently & - & $\begin{array}{c}(1.4)- \\
1.6-6.8- \\
(8.7)\end{array}$ & $\begin{array}{c}/ 2.1-7.7- \\
(12.8)\end{array}$ & $\begin{array}{l}\text { Dripping } \\
\text { sandstone } \\
\text { rocks } \\
\end{array}$ \\
\hline O. hafneriensis & $1.4-2.4$ & common & absent & $1.1-1.9$ & $\begin{array}{c}\text { absent/ } \\
\text { weak }\end{array}$ & sometimes & - & $1.0-4.4$ & $\begin{array}{c}1.0-1.7 / \\
2.0-5.8\end{array}$ & Lake benthos \\
\hline O. kauaiensis & $1.2-1.7$ & common & absent & $0.9-1.4$ & $\begin{array}{c}\text { absent/ } \\
\text { weak }\end{array}$ & absent & - & $1.0-4.4$ & $\begin{array}{c}0.9-1.5 / \\
1.3-7.8\end{array}$ & Sea cave \\
\hline
\end{tabular}

* We did not include $O$. subterranea in the comparative table because of obvious morphological and ecological differences with our strains. ** After Osorio-Santos et al., 2014.

color, much longer intercalary cells, and the shape and dimensions of apical cells. Ukrainian species also differ from already known representatives of the genus by the appearance and width of trichomes, the length of intercalary and apical cells.

In their ecology, both new species are terrestrial xerophytes. On the marine beach, where they were initially revealed, the biota is exposed to high solar radiation and salinity of the environment; water stress is mitigated by the proximity of the sea. For chalk outcrops, where $O$. ucrainica is common, the main limiting factor is the lack of moisture. It is logical to assume that morphologically and in molecular features Ukrainian species would be closer to the "desert" group of Oculatella (O. atacamensis, O. coburnii, $O$. mojaviensis, O. neakameniensis) than to species from aquatic habitats $(O$. cataractarum Bohunická et Johansen, $O$. hafneriensis, $O$. kauaiensis Miscoe et Johansen). A comparative analysis of the main morphological features of Oculatella species (Table 2) shows that the width of the filaments of $O$. ucrainica is indeed similar to the "desert" and differs from "aquatic" species, but in the trichome width it exceeds all known species of genus Oculatella. Morphologically $O$. ucrainica is the most similar to $O$. coburnii: common features are constrictions at cross walls and length of intercalary cells. It is interesting that $O$. ucrainica represents the sister lineage to $O$. coburnii in $16 \mathrm{~S}-23 \mathrm{~S}$ ITS phylogeny (Fig. 2) and shows most similarties in the secondary structure of 16S-23S ITS region (Fig. 3). TEM investigation of $O$. ucrainica strains showed 4-6 parietal thylakoids in vegetative cells and dark granules near cross walls (Fig. 6). The ultrastructure with parietal arrangement of thylakoids are typical for both other species of Oculatella (Zammit et al., 2012; Osorio-Santos et al., 2014) and representatives of Synechococcales.

The appearance and dimensional features of O. kazantipica differ from other species of this genus to a lesser degree: the distinctive characters are the upper limit of the filament width, and the clearly visible granulations at cell walls; they are also present in $O$. cataractarum. Morphologically $O$. kazantipica is most similar to $O$. hafneriensis and $O$. neakameniensis: 


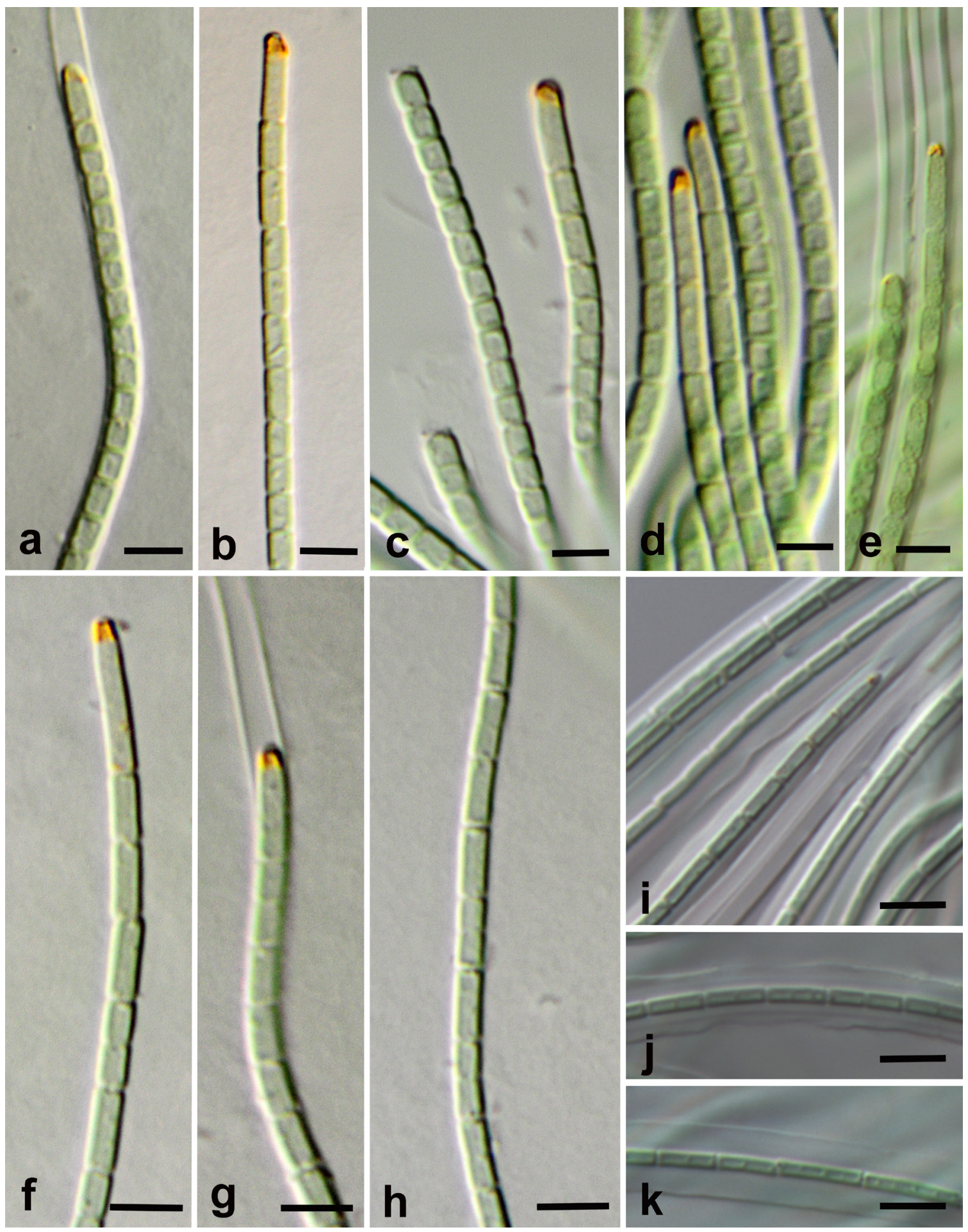

Fig. 4. Micrographs of new species of Oculatella; $O$. ucrainica sp. nov.: $a-d-$ young filaments of strains KZ-5-4-1 $(a-c)$ and KZ-12-1 $(d)$ with clear photosensitive granules in terminal cells, $e$ - old filament with narrow sheath (KZ-5-4-1); O. kazantipica sp. nov. (KZ-19-s-2): $f-h-$ young filaments with clear photosensitive granules in terminal cells and narrow sheath (g), $i-k-$ old filaments with wide and slightly lamellar sheaths. Scale $5 \mu \mathrm{m}$ 
Fig. 5. Drawings of new species of Oculatella. O. ucrainica sp. nov. (KZ5-4-1): $a$ - young filaments, $b$ - old filament; $O$. kazantipica sp. nov. (KZ19-s-2): $c$ - young filaments, $d$ - old filament. Scale $5 \mu \mathrm{m}$

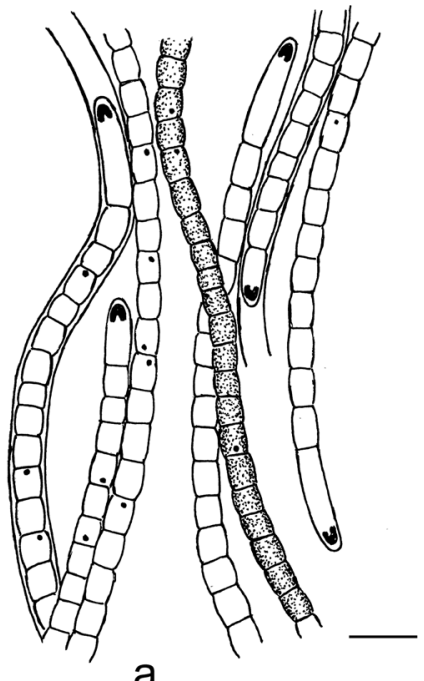

a

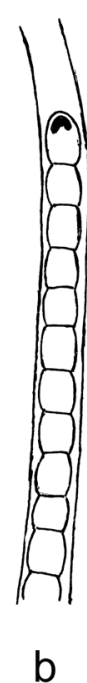

b

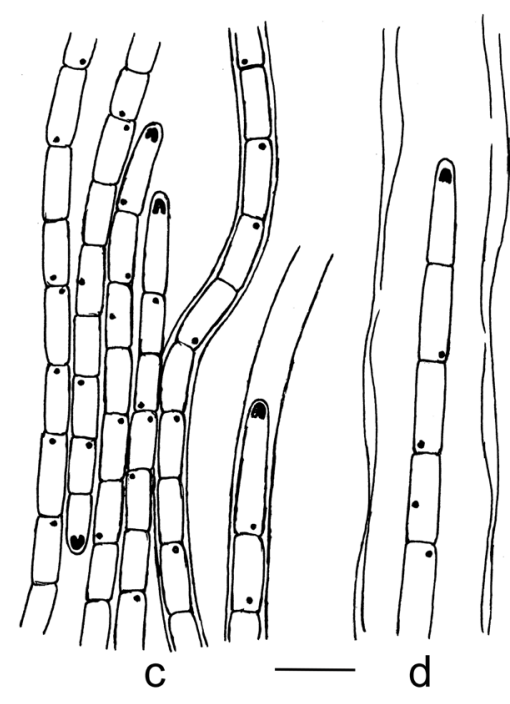

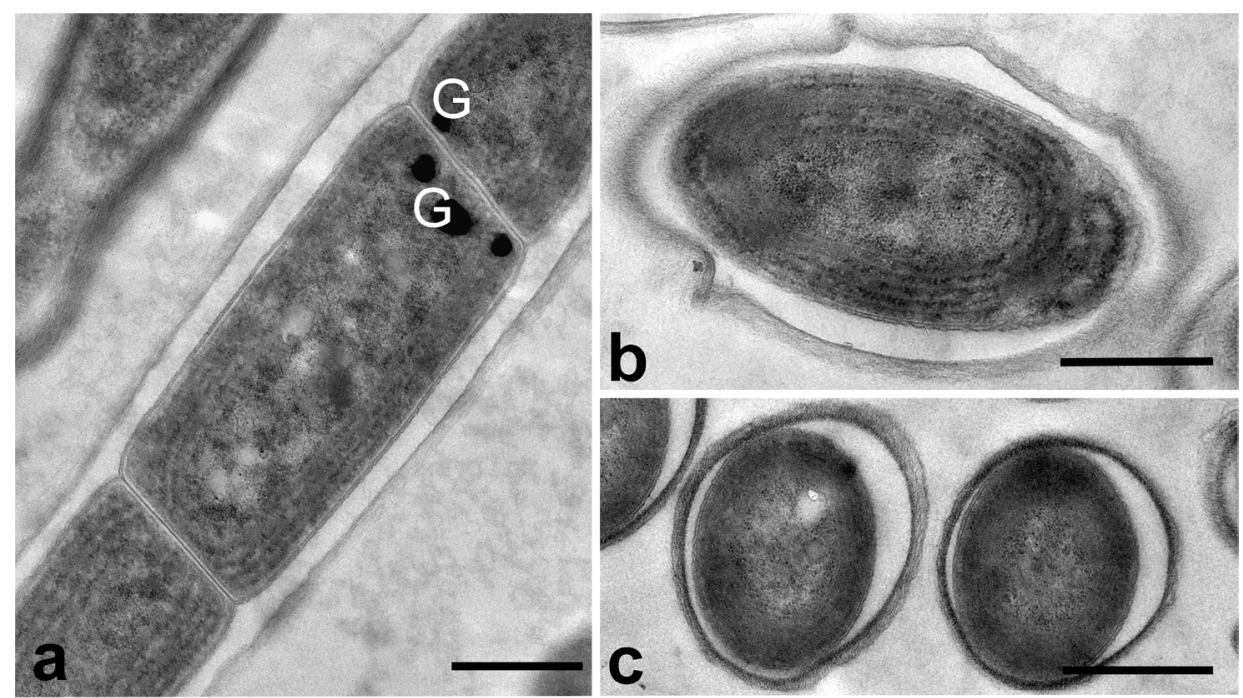

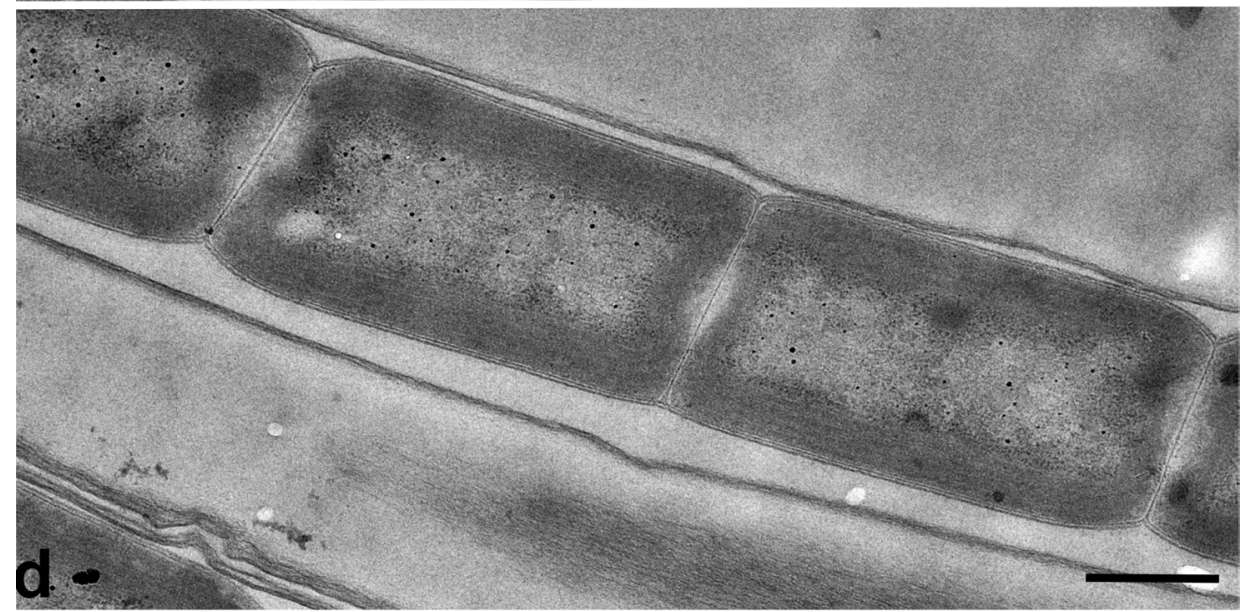

Fig. 6. Transmission electron micrographs of Oculatella ucrainica: $a, d$ - longitudinal section of filaments, $b, c-$ cross sections of filaments; $a-c-$ strain KZ-5-4-1, $d-$ strain KZ-12-1. Strains are characterized by parietal thylakoids and the presence of granules (marked G). Scale $1 \mu \mathrm{m}$ 
common features are trichome width, lack of constrictions at cross walls, shape and dimensions of apical cells. $O$. kazantipica phylogenetically is close to both mentioned above species (Fig. 2) and represents similar secondary structure of $16 \mathrm{~S}-23 \mathrm{~S}$ ITS region, especially close to unique $\mathrm{V}-2$ helix of $O$. hafneriensis (Fig. 3).O. neakameniensis is a terrestrial species isolated from semiarid volcanic soil (Greece) and therefore ecologically similar to our isolate. The phylogenic position of $O$. hafneriensis between terrestrial species is surprising because this species is inhabiting fresh waters and occupies basic phylogenetic position among other aquatic representatives in Osorio-Santos et al. (2014). But $O$. neakameniensis, $O$. hafneriensis and our isolate KZ-19-s-2 are close biogeographically because were isolated in Europe and differ from other known species found from tropical islands, North and South America. $O$. hafneriensis were originally described from benthos of a temperate lake in Austria (Osorio-Santos et al., 2014).

\section{Taxonomic descriptions}

Oculatella ucrainica O.M. Vynogr. et Mikhailyuk sp. nov.

Diag no sis: Morphologically and phylogenetically is the most similar to $O$. coburnii, from which differs in the higher degree of sheath formation, wider trichomes, apical cells without irregular outgrowth and by composition and secondary structure of 16S-23S ITS region.

Thallus flat, thin, spreading diffusely from the center, penetrating intothe agar, blue-green. Filamentsflexuous, (1.5)1.9-2.5(3.0) $\mu \mathrm{m}$ wide, mostly unbranched. Sheath very common, nearly obligate in older cultures, thin and tightly attached when young, later distinctly widened, colorless. Trichomes motile only in young state, olivegreen, (1.3)1.7-2.3(2.7) $\mu \mathrm{m}$ wide, clearly constricted at cross walls (especially in young cultures) and sometimes with granules, lacking necridia, not attenuated to the end. Cells isodiametric to longer than wide, (1.3)1.73.7(4.7) $\mu \mathrm{m}$, with nongranular cytoplasm and parietal thylakoids clearly visible in the light microscope. Mature apical cells bluntly conical, longer than vegetative cells, 1.3-1.7(2.3) $\mu \mathrm{m}$ wide, (2.3)3.3-6.7 (7.7) $\mu \mathrm{m}$ long, with a reddish-orange spot in the apex of the cell. D1-D1' helix of the 16S-23S ITS region 64 nucleotides long, with a large subterminal bilateral bulge of 9 nucleotides. V2 helix with only 8 nucleotides. Box-B with 34 nucleotides, with 6 nucleotides in the terminal loop. V3 helix with 52 nucleotides, with a unilateral bulge on the $5^{\prime}$ side of the helix.

$\mathrm{Hab}$ it at: isolated from biological crusts dominated by Nostoc edaphicum and Hassalia sp. on the surface of coquina, clay and chalk outcrops, and hypolitically under pieces of quartz.

Type locality:The coast of the Sea of Azov, vicinities of Kazantip Nature Reserve, Aqtash Lake spit.

I c o n o t y pe: Figs $4 a-c, e, 5 a, b$.

Holotype here designated: $K W-A$ 32375, Herbarium of M.G. Kholodny Institute of Botany of NAS of Ukraine.

Reference strain: KZ-5-4-1 (SAG 2563).

Additional strains: KZ-7-1-4, KZ-12-1, Vin-4-4-1.

Additional sampling localities: the coast of the Sea of Azov, Kazantip Nature Reserve, Sharabay Bay. Kharkiv Region, Dvorichansky District, vicinities of PetroIvanivka village.

Et y molog y: ucrainica $=$ from Ukraine.

Oculatella kazantipica O.M. Vynogr. et Mikhailyuk sp. nov.

Diagn o s is: Morphologically and phylogenetically it is the most similar to $\mathrm{O}$. hafneriensis and O. neakameniensis, from which differs in higher degree of sheath formation, false branching, granulations at cross walls and longer intercalary cells, and by composition and secondary structure of $16 \mathrm{~S}-23 \mathrm{~S}$ ITS region.

Thallus a thin film penetrating into the agar, spreading diffusely from the center of thallus, bluegreen. Filaments weakly waved, rarely with false branching or more than one trichome in common sheath. Sheath nearly obligate, first thin and tightly attached, (1.3)1.5-1.9 $\mu \mathrm{m}$ wide, in old cultures firm, gradually expanded, sometimes lamellate, 5-7.5 $\mu \mathrm{m}$ wide, colorless. Trichomes olive-green, (1.1)1.3$1.7 \mu \mathrm{m}$ wide, unconstricted to slightly constricted at the cross walls (especially in young cultures) often flanking with granules, lacking necridia, not attenuated to the end. Cells consistently longer than wide, with nongranular cytoplasm, with parietal thylakoids clearly visible in the light microscope, (2)2.3-4.7(5) $\mu \mathrm{m}$ long, in old cultures up to $7.5 \mu \mathrm{m}$ long. Mature apical cells elongated-conical, longer than vegetative cells, 1.3$1.5 \mu \mathrm{m}$ wide, (4.0)5.0-7.0(8.7) $\mu \mathrm{m}$ long, with a reddishorange spot in the apex of the cell. D1-D1' helix of the 16S-23S ITS region 64 nucleotides long, with a large subterminal bilateral bulge of 9 nucleotides. V2 helix 15 nucleotides long, with a terminal loop of 7 nucleotides. Box-B with 34 nucleotides, with 6 nucleotides in the terminal loop. V3 helix region with 53 nucleotides, with a unilateral bulge on the $5^{\prime}$ side of the helix at nucleotides. 
Habitat: coquina beach exposed to direct sunlight, in biological crusts with dominance of Microcoleus vaginatus at seaside.

Type locality: The coast of the Sea of Azov, Kazantip Nature Reserve, Shyrokaya Bay.

I c o n ot y pe: Figs $4 f-k, 5 c, d$.

Holotype here designated: $K W-A$ 32376, Herbarium of M.G. Kholodny Institute of Botany of NAS of Ukraine.

Reference strain: KZ-19-s-2 (SAG 2567).

Etymology: kazantipica $=$ from the Cape Kazantip.

In contrast to previous studies, which reported Oculatella as a rare genus (Osorio-Santos et al., 2014), we found this genus in over half of our soil crust samples from the Sea of Azov coast and chalk outcrops in Kharkiv Region. Recent studies suggest that Oculatella might be even more widely distributed as it was found in biological soil crust in Iran (Dulić et al., 2017). From the isolated strains, we described two new species after detailed investigations of their morphology, phylogeny, and ultrastructure. Both, the morphological and phylogenetic characterstics, indicate that the new strains represent new species. This is strengthen by the ecology and biogeography of the new strains, both different to the previously describted Oculatella species. It is interesting that type populations of these new species were found on small territory of Kazantip Nature Reserve and vicinities similar to the earlier described species $O$. coburnii and $O$. mojaviensis found also on a limited territory, in desert soils of California, USA. Moreover, the terrestrial species O. kazantipica is morphologically and genetically close to the freshwater European taxon O. hafneriensis.

\section{Acknowledgements}

The research was supported by a Georg-Forster Fellowship of the Alexander von Humboldt Foundation (Alexander von Humboldt Stiftung) to the second author. We are grateful to Dr. Alla B. Gromakova, V.N. Karazin National University, Ukraine, for the samples of biological crusts collected in Kharkiv Region. We thank Sabrina Obwegeser, Beatrix Jungwirth and Lisa Obwegs, University of Innsbruck, Austria, for providing help in the TEM investigations, Jeffrey R. Johansen, John Carroll University, University Heights, USA, for providing original sequence of Oculatella hafneriensis, Dr. Maike Lorenz, University of Göttingen, Germany, for help during strain deposition to $S A G$, as well as Eduard Demchenko, M.G. Kholodny Institute of Botany of NASU, for help during cultivation of Oculatella strains.

\section{REFERENCES}

Akaike H. A new look at the statistical model identification. IEEE Trans. Automat. Contr., 1974, 19(6): 716-723.

Bischoff H.W., Bold H.C. Phycological studies. IV. Some soil algae from Enchanted Rock and related algal species. Univ. Texas Publ., 1963, 6318: 1-95.

Byun Y., Han K. PseudoViewer3: generating planar drawings of large-scale RNA structures with pseudoknots. Bioinformatics, 2009, 25(11): 1435-1437.

Dulić T., Meriluoto J., Malešević T.P., Gajić V., Važić T., Tokodi N., Obreht I., Kostić B., Kosijer P., Khormali F., Svirčev Z. Cyanobacterial diversity and toxicity of biocrusts from the Caspian Lowland loess deposits, North Iran. Quat. Int., 2017, 429: 74-85

Holzinger A., Roleda M.Y., Lütz C. The vegetative arctic green alga Zygnema is insensitive to experimental UV exposure. Micron, 2009, 40: 831-838.

Katoh K., Standley D.M. MAFT Multiple Sequence Alignment Software Version 7: improvements in performance and usability. Mol. Biol. and Evol., 2013, 30(4): 772-780.

Marin B., Nowack E.C.M., Melkonian M. A plastid in the making: evidence for a second primary endosymbiosis. Protist, 2005, 156: 425-432.

Mikhailyuk T.I., Vinogradova O.N., Glaser K., Karsten U. New taxa for the flora of Ukraine, in the context of modern approaches to taxonomy of Cyanoprokaryota/ Cyanobacteria. Int. J. on Algae, 2016, 18(4): 301-320.

Osorio-Santos K., Pietrasiak N., Bohunická M., Miscoe L.H., Kováčik L., Martin M.P., Johansen J.R. Seven new species of Oculatella (Pseudanabaenales, Cyanobacteria): taxonomically recognizing cryptic diversification. Eur. J. Phycol., 2014, 49(4): 450-470.

Ronquist F., Huelsenbeck J.R. MrBayes 3: Bayesian phylogenetic interference under mixed models. Bioinformatics, 2003, 19(12): 1572-1574.

Stanier R.Y., Kunisawa R., Mandel M., Cohen-Bazire G. Purification and properties of unicellular blue-green algae (order Chroococcales). Bacteriol. Rev., 1971, 35: 171-205.

Tamura K., Stecher G., Peterson D., Filipski A. MEGA6: molecular evolutionary analysis version 6.0. Mol. Biol. and Evol., 2013, 30(12): 2725-2729.

Wilmotte A., Van der Auwera G., De Wachter R. Structure of the $16 \mathrm{~S}$ ribosomal RNA of the thermophilic cyanobacterium Chlorogloeopsis HTF (Mastigocladus laminosus HTF') strain PCC75 18, and phylogenetic analysis. FEBS Lett., 1993, 317(1-2): 96-100.

Zammit G., Billi D., Albertano P. The subaerophytic cyanobacterium Oculatella subterranea (Oscillatoriales, Cyanophyceae) gen. et sp. nov.: a cytomorphological and molecular description. Eur. J. Phycol., 2012, 47: 341-354.

Zuker M. Mfold web server for nucleic acid folding and hybridization prediction. Nucl. Acid Res., 2003, 31(13): 3406-3415.

Recommended for publication by P.M. Tsarenko
Submitted 01.07.2017

Укр. бот. журн., 2017, 74(6) 
Виноградова О.М. ${ }^{1}$, Михайлюк T.I. ${ }^{1}$, Глазер К. ${ }^{2}$, Хольцингер А. ${ }^{3}$, Карстен У. ${ }^{2}$ Нові види роду Oculatella (Synechococcales, Cyanobacteria) з наземних місцезростань України. Укр. бот. журн., 2017, 74(6): 509-520.

${ }^{1}$ Інститут ботаніки ім. М.Г. Холодного НАН України вул. Терещенківська, 2, Київ 01004, Україна

${ }^{2}$ Університет м. Росток, Інститут біологічних наук Альберт Ейнштейн штрассе, 3, Росток D-18057,

Німеччина

${ }^{3}$ Університет м. Інсбрук, кафедра ботаніки

Штернвартештрассе, 15, Інсбрук А-6020, Австрія

Описані нові для науки види з роду Oculatella Zammit, Billi \& Albertano: O. ucrainica sp. nov. та O. kazantipica sp. nov., виділені з біологічних кірочок, відібраних на ракушняковому пляжі біля Азовського моря (АР Крим), а також на крейдяних та глинистих схилах у Харківській області. Комплексне дослідження п'яти отриманих штамів Oculatella показало, що фенотипично та філогенетично вони відрізняються від усіх відомих видів цього роду. На філогенетичному дереві, побудованому на основі порівняння послідовностей генів $16 \mathrm{~S} p \mathrm{PHK}$, штами нових видів приєднались до вже відомих видів Oculatella, які утворювали окремі лінії, при цьому один 3 них (O. ucrainica) увійшов до групи засухостійких наземних видів, а інший (O. kazantipica) потрапив до однієї клади з терестріальним видом O. neakameniensis Kováčik et Johansen та озерним O. hafneriensis Kováčik \& Johansen. Філогенетичний аналіз за ділянкою $16 \mathrm{~S}$ pРНК, зв'язаною 3 регіоном 16S-23S ITS, а також вторинні структури найінформативніших хеліксів $16 \mathrm{~S}-23 \mathrm{~S}$ ITS підтвердили виділення нових видів, які морфологічно також чітко відрізняються. Нитки O. ucrainica вужчі (1,5-3,0 мкм), а трихоми ширші (1,32,7 мкм), ніж у O. kazantipica (нитки 1,3-7,5 мкм шир., трихоми 1,1-1,7 мкм шир.), є відмінності у морфогенезі піхов, перетягнутості трихомів та довжині клітин. Oculatellaucrainica найбільшподібнийдопустельного виду O. coburnii Pietrasiak \& Johansen, від якого відрізняється інтенсивністю формування піхов, ширшими трихомами, відсутністю неправильного виросту на кінцевих клітинах, а також конфігурацією вторинної структури регіону 16S-23S ITS. Oculatella kazantipica близька до $O$. hafneriensis та $O$. neakameniensis, від яких відрізняється за морфологією піхов, наявністю несправжнього галуження, грануляціями біля поперечних перегородок, більшою довжиною інтеркалярних клітин, та деталями будови вториннної структури регіону 16S-23S ITS.

Ключові слова: Synechococcales, Oculatella ucrainica, O. kazantipica, нові види, біологічні корочки, Україна, молекулярна філогенія, 16S pPHK, 16S-23S ITS, вторинна структура
Виноградова О.Н. ${ }^{1}$, Михайлюк Т.И. ${ }^{1}$, Глазер К. ${ }^{2}$, Хольцингер А. ${ }^{3}$, Карстен У. ${ }^{2}$ Новые виды рода Oculatella (Synechococcales, Cyanobacteria) из наземных местообитаний Украины. Укр. бот. журн., 2017, 74(6): 509-520.

${ }^{1}$ Институт ботаники им. Н.Г. Холодного НАН Украины ул. Терешенковская, 2, Киев 01004, Украина

${ }^{2}$ Университет г. Росток, Институт биологических наук Альберт Эйнштейн штрассе, 3, Росток D-18057,

Германия

${ }^{3}$ Университет г. Инсбрук, кафедра ботаники Штернвартештрассе, 15, Инсбрук А-6020, Австрия

Описаны новые для науки виды из рода Oculatella Zammit, Billi \& Albertano: O. ucrainica sp. nov. и O. kazantipica sp. nov., выделенные из биологических корочек, отобранных на ракушечниковом пляже у Азовского моря (АР Крым), а также на меловых и глинистых склонах в Харьковской обл. Комплексное исследование пяти полученных штаммов Oculatella показало, что фенотипически и филогенетически они отличаются от всех известных видов этого рода. На филогенетическом дереве, построенном на основе сравнения последовательностей генов $16 \mathrm{~S} p \mathrm{PHK}$, штаммы новых видов присоединялись к уже известным видам Oculatella, образующим отдельные линии, при этом один из них (O. ucrainica) вошел в группу засухоустойчивых наземных видов, а другой (O. kazantipica) попал в одну кладу с наземным видом $O$. neakameniensis Kováčik et Johansen и водным $O$. hafneriensis Kováčik \& Johansen. Филогенетический анализ по участку $16 \mathrm{~S} p \mathrm{PHK}$, связанному с регионом 16S-23S ITS, а также вторичные структуры наиболее информативных хеликсов 16S-23S ITS подтвердили выделение новых видов, которые морфологически также хорошо различимы между собой. Нити 0 . ucrainica у́же (1,5-3,0 мкм), а трихомы шире $(1,3-2,7 \mu \mathrm{m})$, чем у O. kazantipica (нити 1,3-7,5 мкм шир., трихомы 1,11,7 мкм шир.), отличия также касаются морфогенеза влагалища, перешнурованности трихомов и длины клеток. Oculatella ucrainica наиболее сходен с пустынным видом O. coburnii Pietrasiak \& Johansen, от которого отличается интенсивностью формирования влагалища, более широкими трихомами, отсутствием неправильного выроста на конечных клетках, a также конфигурацией вторичной структуры региона 16S-23S ITS. Oculatella kazantipica близка к $O$. hafneriensis и $O$. neakameniensis, от которых отличается морфологией влагалища, наличием ложного ветвления, грануляциями у поперечных перегородок, большей длиной интеркалярных клеток и деталями строения вторичной структуры региона $16 \mathrm{~S}-23 \mathrm{~S}$ ITS.

Ключевые слова: Synechococcales, Oculatella ucrainica, O. kazantipica, новые виды, биологические корочки, Украина, молекулярная филогения, 16S pPHK, 16S-23S ITS, вторичная структура 
Electronic Supplement to: Vinogradova \& al. New species of Oculatella...

Ukr. Bot. J., 2017, 74(6)

Table E1. List of species and strains used for the 16S rRNA and 16S-23S ITS sequence comparisons

\begin{tabular}{|c|c|c|c|}
\hline \multirow{2}{*}{ Species } & \multirow{2}{*}{ Strain } & \multicolumn{2}{|c|}{ Accession number ${ }^{1}$} \\
\hline & & 16S rRNA & 16S-23S ITS region \\
\hline Oculatella ucrainica sp. nov. & KZ-5-4-1, SAG 2563 & KY098843 & MG652620 \\
\hline Oculatella ucrainica sp. nov. & $\mathrm{KZ}-7-1-4$ & KY098844 & MG652619 \\
\hline Oculatella ucrainica sp. nov. & Vin-4-4-1 & \multicolumn{2}{|c|}{ MG652618 } \\
\hline Oculatella ucrainicasp. nov. & KZ-12-1 & \multicolumn{2}{|c|}{ MG652617 } \\
\hline Oculatella kazantipica sp. nov. & KZ-19-s-2, SAG 2567 & \multicolumn{2}{|c|}{ MG652616 } \\
\hline Oculatella hafneriensis & Hindak 1982/12 & \multicolumn{2}{|c|}{ MG652621 ${ }^{2}$} \\
\hline Oculatella atacamensis & ATA3-4Q-CV5 & \multicolumn{2}{|c|}{ KF761582 } \\
\hline Oculatella atacamensis & ATA2-1-CV24 & - & KF761575 \\
\hline Oculatella mojaviensis & CMT-3BRINC87 & \multicolumn{2}{|c|}{ KF761572 } \\
\hline Oculatella mojaviensis & CMT-3BRINC84 & - & KF761571 \\
\hline Oculatella coburnii & WJT66-NPBG6A & \multicolumn{2}{|c|}{ KF761586 } \\
\hline Oculatella coburnii & WJT36-NPbg13 & - & HM018687 \\
\hline Oculatella neakameniensis & Kovacik 1990/54 & \multicolumn{2}{|c|}{ EU528672 } \\
\hline Oculatella neakameniensis & Kovacik 1990/37 & - & EU528671 \\
\hline Oculatella sp. & LLi18 & \multicolumn{2}{|c|}{ DQ786166 } \\
\hline Oculatella kauaiensis & HA4348 LM1 & & \\
\hline Oculatella subterranea & VRUC135 & & \\
\hline Oculatella cataractarum & GSE-PSE-MK52-07L & & \\
\hline Leptolyngbya sp. & Uher $2000 / 2452$ & & \\
\hline Leptolyngbya frigida & ANT.L52.2 & AY493575 & - \\
\hline Leptolyngbya frigida & ANT.L70.1 & AY493574 & - \\
\hline Pseudanabaenales cyanobacterium & WJT40-NPBG3 & KJ939003 & - \\
\hline Leptolyngbya sp. & GSE-PSE28-08A & HM018691 & - \\
\hline Leptolyngbya compacta & GSE-PSE28-08A & HQ132933 & - \\
\hline Phormidium sp. & РMC301.07 & GQ859651 & - \\
\hline Schizothrix arenaria & HA4233-MV5 & JN385286 & - \\
\hline Leptolyngbya antarctica & ANT.LG2.5 & AY493603 & - \\
\hline Leptolyngbya antarctica & ANT.L18.1 & AY493607 & - \\
\hline Leptolyngbya antarctica & ANT.L67.1 & AY493572 & - \\
\hline Leptolyngbya laminosa & ETS-08 & FM210757 & - \\
\hline Leptolyngbya tenerrima & AF218368 & UTCC 77 & - \\
\hline Leptolyngbya boryana & PCC 6306 & EF429289 & - \\
\hline Leptolyngbya boryana & CCAP 1446/2 & HF678483 & - \\
\hline Leptolyngbya foveolarum & VP1-08 & FR798945 & - \\
\hline Leptolyngbya sp. & HA4236-MV8 & KJ939018 & - \\
\hline Pseudophormidium sp. & WJT71-NPBG25 & KJ939062 & - \\
\hline Pseudophormidium sp. & ATA5-5-1-KO9 & KC311902 & - \\
\hline Alkaline mapantanalense & CENA531 & KF246497 & - \\
\hline Alkaline mapantanalense & CENA530 & KF246496 & - \\
\hline Phormidesmis priestleyi & ANT.L66.1 & AY493581 & - \\
\hline Phormidesmis priestleyi & ANT.LG2.4 & AY493580 & - \\
\hline Phormidesmis sp. & WJT36-NPBG15 & KJ939033 & - \\
\hline Leptolyngbya sp. & HA4254-MV3 & KJ939090 & - \\
\hline Leptolyngbya sp. & HA4230-MV4 & КC525093 & - \\
\hline Leptolyngbya frigida & ANT.L52B.3 & AY493612 & - \\
\hline Leptolyngbya frigida & ANT.L64B.1 & AY493577 & - \\
\hline Leptolyngbya tenuis & РMC304.07 & GQ859652 & - \\
\hline Pseudanabaena tremula & UTCC 471 & AF218371 & - \\
\hline Pantanaline marosaneae & CENA539 & KF246503 & - \\
\hline Pantanaline marosaneae & CENA521 & KF246488 & - \\
\hline Nodosilinea epilithica & Kovacik 1998/7 & HM018677 & - \\
\hline Nodosilinea epilithica & Kovacik 1990/52 & HM018679 & - \\
\hline Leptolyngbya margaretheana & $1 \mathrm{~T} 12$ & FR798934 & - \\
\hline Nodosilinea nodulosa & UTEX 2910 & KF307598 & - \\
\hline Nodosilinea conica & SEV4-5-c1 & EU528667 & - \\
\hline Nodosilinea sp. & Prim-5-5 & KY098847 & - \\
\hline Nodosilinea bijugata & Kovacik 1986/5a & EU528669 & - \\
\hline Oscillatoria neglecta & AM M-82 & AB003168 & - \\
\hline Leptolyngbya subtilissima & EcFYyyy700 & KC463197 & - \\
\hline Phormidesmis priestleyi & ANT.LACV5.1 & AY493586 & - \\
\hline Phormidesmis priestleyi & ANT.LPR2.5 & AY493620 & - \\
\hline Pseudophormidium sp. & ANT.LPE.3 & AY493587 & - \\
\hline Trichocoleus desertorum & ATA4-8-CV2 & KF307604 & - \\
\hline Trichocoleus badius & CRS-1 & EF429297 & - \\
\hline Pseudanabaena minima & GSE-PSE20-05C & HQ132935 & - \\
\hline Limnothrix redekei & CCAP 1443/1 & AJ580007 & - \\
\hline Phormidium mисіcola & IAM M-221 & AB003165 & - \\
\hline Gloeobacter violaceus & PCC 7421 & NR074282 & - \\
\hline
\end{tabular}

